\title{
PENGARUH KOMPETENSI SUMBER DAYA MANUSIA, TEKNOLOGI INFORMASI, REVIU LAPORAN KEUANGAN DAN SISTEM PENGENDALIAN INTERNAL TERHADAP KUALITAS LAPORAN KEUANGAN PADA PEMERINTAH PROVINSI SULAWESI UTARA
}

\author{
Merlyn C. T. Kalumata, Ventje Ilat, Jessy D. L. Warongan \\ (email:merlyn_ck@yahoo.com)
}

\begin{abstract}
This study aims to examine the effect of human resources competence, information technology, review of financial statement and internal control system on the quality of financial statement in Government of North Sulawesi. The variables in this study consist of independent variable :human resources competence (X1), information technology (X2), review of financial statement (X3) and internal control system (X4).On the other hand, the dependent variable is the quality of financial statement $(Y)$. Data were analyzed by multiple linear regression analysis (multiple regression). The results indicate that human resources competence, information technology, review of financial statement and internal control system simultaneously have a significant influence on the quality of financial statement. The value of the coefficient of determination shows that human resources competence, information technology, review of financial statement and internal control system simultaneously contribute to the quality of financial statement. $R^{2}$ is $71.3 \%$, it means those dependent variables affect the quality of financial statement by $71.3 \%$. While the remaining of $28.7 \%$ is influenced by other variables which are excluded within this research. Partial test results show that information technology, review of financial statement and internal control system have a significant impact on the quality of financial statement. Human resources competence has no significant impact on the quality of financial statement.
\end{abstract}

Keywords : quality of financial statement, human resources competence, information technology, review of financial statement, internal control system

\section{PENDAHULUAN}

Hasil audit Badan Pemeriksa Keuangan (BPK) terhadap LKPD seluruh Indonesia menunjukkan masih banyak pemerintah daerah yang belum memperoleh opini Wajar Tanpa Pengecualian(WTP). Untuk tahun pelaporan 2015, BPK mencatat hanya 58\% atau 312 LKPD yang memperoleh opini WTP. Sementara itu LKPD lainnya tercatat memperoleh opini Wajar Dengan Pengecualian (WDP) sebanyak 187 LKPD, Tidak Menyatakan Pendapat (TMP) sebanyak 30 LKPD, dan masih ada 4 LKPD yang memperoleh opini Tidak Wajar (TW). Namun secara keseluruhan pengelolaan keuangan daerah semakin baik setiap tahun, hal ini ditandai dengan terus meningkatnya persentase opini WTP, penurunan WDP dan TMP. Dibandingkan dengan tahun 2014, LKPD yang mendapat opini WTP mengalami kenaikan dari $47 \%$ menjadi 58\%. Kenaikan kualitas ini didukung oleh upaya pemerintah daerah memperbaiki kelemahan yang terjadi sepanjang tahun 2014.

Hal ini menggambarkan adanya perbaikan yang dicapai oleh entitas pemerintah daerah dalam menyajikan suatu laporan keuangan yang wajar sesuai dengan prinsip yang berlaku. Hasil evaluasi BPK menunjukkan bahwa LKPD yang memperoleh opini WTP dan WDP pada umumnya memiliki pengendalian internal yang telah memadai. Adapun LKPD yang memperoleh opini TW dan TMP memerlukan perbaikan pengendalian internal.

Sesuai dengan amanat UU NO.17 Tahun 2003 Pemerintah Daerah berkewajiban mengimplementasikan akuntansi berbasis akrual dalam penyajian laporan keuangan secara penuh pada tahun 2015. Laporan keuangan berbasis akrual dimaksud untuk memberi manfaat lebih baik bagi para pemangku kepentingan. Hasil Pemeriksaan BPK pada Pemerintah 
Provinsi Sulawesi Utara atas efektivitas upaya pemerintah daerah dalam implementasi Standar Akuntansi Pemerintahan berbasis akrual tahun 2014 dan 2015 (sampai dengan triwulan III) masih terdapat beberapa permasalahan antara lain: (1) perangkat regulasi dan kebijakan terkait implementasi SAP berbasis akrual belum sepenuhnya mendukung SAP berbasis akrual dan diimplementasikan, (2) analisis kebutuhan SDM pengelola keuangan,aset dan teknologi informasi serta inspektorat selaku pereviu LKPD belum memadai, menyangkut analisis kebutuhan maupun optimalisasi SDM, dan (3) dari aspek pengelolaan teknologi, pemerintah daerah belum melakukan analisis sistem aplikasi yang dibutuhkan untuk implementasi SAP berbasis akrual, sistem aplikasi yang dimiliki belum sesuai kebutuhan untuk mengimplementasikan SAP berbasis akrual, dan pemerintah daerah belum membuat rencana dan melakukan evaluasi periodik atas sistem aplikasi tersebut.

Perubahan akuntansi berbasis kas menjadi akrual bukan sekedar masalah teknis pencatatan transaksi dan menyajikan laporan keuangan, tetapi membutuhkan kebijakan akuntansi (accounting policy), perlakuan akuntansi untuk suatu transaksi (accounting treatment), pilihan akuntansi (accounting choice), serta mendesain atau menganalisis sistem akuntansi yang ada. Oleh karenanya, proses pelaporan keuangan pemerintah harus dikerjakan oleh SDM yang memiliki kompetensi agar mampu menyusun dan menyajikan LKPD yang berkualitas.

Inspektorat sebagai Aparat Pengawasan Intern Pemerintah adalah instansi pemerintah yang dibentuk dengan tugas melaksanakan pengawasan internal di lingkungan pemerintah pusat dan/atau pemerintah daerah. Salah satu kegiatan pengawasan internal yaitu melalui kegiatan reviu atas LKPD sesuai dengan Peraturan Pemerintah Nomor 8 Tahun 2006 tentang Pelaporan Keuangan dan Kinerja Instansi Pemerintah, pasal 33 ayat (3) yang menyebutkan bahwa Inspektorat Provinsi/Kabupaten/Kota melakukan reviu atas laporan keuangan dan kinerja dalam rangka meyakinkan keandalan informasi yang disajikan sebelum disampaikan oleh Gubernur/Bupati/Walikota kepada BPK.

Sebelum diaudit oleh BPK, LKPD telah direviu terlebih dahulu oleh Inspektorat, untuk memberikan keyakinan terbatas atas laporan keuangan bahwa tidak ada modifikasi material yang harus dilakukan atas laporan keuangan dan LKPD sudah disajikan berdasarkan Sistem Pengendalian Intern (SPI) yang memadai dan sesuai dengan Standar Akuntansi Pemerintah (SAP), seperti diamanatkan dalam Peraturan Menteri Dalam Negeri No.4 Tahun 2008 tentang Pedoman Pelaksanaan Reviu atas LKPD Pasal 3 ayat (1) menegaskan bahwa Reviu atas Laporan Keuangan Pemerintah Daerah dilakukan untuk memberikan keyakinan atas kualitas laporan keuangan pemerintah daerah. Oleh karena itu, proses reviu menjadi krusial untuk dilaksanakan oleh Pemerintah Daerah dalam rangka melaksanakan amanah peraturan perundangan dan dalam rangka mewujudkan tata kelola yang lebih baik.

Berdasarkan fenomena tersebut, kualitas laporan keuangan yang dihasilkan oleh pemerintah daerah dipengaruhi oleh beberapa faktor. Mengingat bahwa karakterisktik kualitatif merupakan unsur penting dalam Laporan Keuangan Pemerintah Daerah sebagai dasar pengambilan keputusan, maka peneliti tertarik untuk meneliti faktor-faktor dapat mempengaruhi kualitas laporan keuangan pemerintah daerah.

Berdasarkan penelitian terdahulu bahwa terdapat tingkat signifikansi yang berbeda dari masing-masing variabel, maka penelitian ini untuk meneliti kembali faktor-faktor penentu kualitas laporan keuangan pemerintah daerah yaitu kompetensi SDM, teknologi informasi, reviu laporan keuangan dan sistem pengendalian internal dengan mengambil objek penelitian pada Pemerintah Daerah Provinsi Sulawesi Utara. 


\section{TINJAUAN PUSTAKA}

\section{Teori Keagenan (Agency Theory)}

Teori keagenan merupakan salah satu teori yang muncul dalam perkembangan riset akuntansi yang merupakan modifikasi dari perkembangan model akuntansi keuangan dengan menambahkan aspek perilaku manusia dalam model ekonomi. Teori keagenan dikembangkan oleh Jensen dan Meckling.

Jensen dan Meckling (1976: 308) menyatakan bahwa:

"We define an agency relationship as a contract under which one or morepersons (the principal(s)) engage another person (the agent) to perform someservice on their behalf which involves delegating some decision making authority to the agent.If both parties to the relationship are utility maximizers there is good reason to believe that the agent will not always act in the best interests ofthe principal."

Prinsip utama teori ini menyatakan adanya hubungan kerja antara pihak yang memberi wewenang (prinsipal) yaitu investor dengan pihak yang menerima wewenang (agen) yaitu manajer, dalam bentuk kontrak kerja sama yang disebut nexus of contract. Agen berkewajiban mempertanggungjawabkan apa yang telah diamanahkan oleh prinsipal kepadanya. Teori ini memiliki asumsi bahwa tiap-tiap individu semata-mata termotivasi oleh kepentingan dirinya sendiri sehingga menimbulkan konflik kepentingan antara prinsipal dan agen.

Laporan keuangan pemerintah daerah merupakan bentuk pertanggungjawaban agen kepada prinsipal atas pengelolaan keuangan daerah yang dibuat sebagai upaya konkrit untuk mewujudkan transparansi dan akuntabilitas pengelolaan keuangan pemerintah daerah, seperti yang diamanatkan dalam Undang-Undang Nomor 17 Tahun 2003 tentang Keuangan Negara dan Undang-Undang Nomor 32 Tahun 2004 Tahun 2004 tentang Pemerintahan Daerah. Semakin menguatnya tuntutan terhadap lembaga-lembaga publik untuk mewujudkan akuntabilitas sektor publik, mengharuskan pemerintah daerah untuk menghasilkan laporan keuangan yang berkualitas.

\section{Laporan Keuangan}

Ikatan Akuntan Indonesia (2012) dalam Standar Akuntansi Keuangan, menyatakan bahwa laporan keuangan merupakan bagian dari proses pelaporan keuangan yang lengkap, biasanya meliputi neraca, laporan laba rugi, laporan posisi keuangan, dan catatan laporan lain serta materi penjelasan yang merupakan bagian integral dari laporan keuangan.

Dalam Peraturan Pemerintah Nomor 71 Tahun 2010 tentang Standar Akuntansi Pemerintahan diatur mengenai unsur laporan keuangan pemerintah berbasis akrual, yang terdiri atas Laporan Pelaksanaan Anggaran (terdiri dari Laporan Realisasi Anggaran dan Laporan Perubahan Saldo Anggaran Lebih), Laporan Finansial (terdiri dari Neraca, Laporan Operasional, Laporan Perubahan Ekuitas, dan Laporan Arus Kas), serta Catatan atas Laporan Keuangan.

Komite Standar Akuntansi Pemerintahan menjelaskan bahwa tanggung jawab penyusunan dan penyajian laporan keuangan berada pada pimpinan entitas. Dalam lingkup pemerintah daerah yang dimaksud dengan pimpinan entitas adalah setiap Kepala Satuan Kerja Perangkat Daerah (SKPD) sebagai entitas akuntansi dan setiap gubernur/ bupati/ walikota sebagai entitas pelaporan. Laporan keuangan SKPD tersebut selanjutnya disampaikan oleh Kepala SKPD kepada Kepala Daerah melalui Pejabat Pengelolaan Keuangan Daerah (PPKD). PPKD adalah Satuan Kerja Pengelola Keuangan Daerah (SKPKD) yang bertindak pula sebagai Bendahara Umum Daerah. PPKD sebagai SKPKD menyusun pula laporan keuangan sebagaimana yang berlaku pada SKPD.

\section{Kualitas Laporan Keuangan}

Agar suatu laporan keuangan dapat memberi manfaat bagi para penggunanya maka 
laporan keuangan tersebut harus mempunyai nilai informasi yang berkualitas dan berguna dalam pengambilan keputusan. Mardiasmo (2009:163) menyatakan bahwa meskipun laporan keuangan bukan merupakan satu-satunya sumber informasi untuk pembuatan keputusan, akan tetapi laporan keuangan sebagai sumber informasi finansial memiliki pengaruh yang sangat besar terhadap kualitas keputusan yang dihasilkan.

Wilkinson, Cerullo, Ravaldan Wong (2000:18) menyatakanbahwa:

"The value of information, and hence the soundness of decisions, canbeaffectedby qualitiesthat attachtotheinformation.Useful informationqualities arerelevance, accuracy,timeliness, conciseness, clarity, quantifiability, andconsistency."

Karakteristik kualitatif informasi laporan keuangan untuk sektor pemerintahan dinyatakan dalam Governmental Accounting Standards Board (GASB, 1999) dalam Concepts Statement No.1 tentang tujuan laporan keuangan yaitu understandable, reliable, relevant, timely, consistent, comparable. Karakteristik tersebut kemudian diadopsi oleh Pemerintah Indonesia dalam Peraturan Pemerintah No. 71 tahun 2010 tentang Standar Akuntansi Pemerintahan yang menyatakan bahwa karakteristik kualitatif laporan keuangan adalah ukuran-ukuran normatif yang perlu diwujudkan dalam informasi akuntansi sehingga dapat memenuhi tujuannya.

\section{Kompetensi Sumber Daya Manusia}

Spencer dan Spencer (1993:9) mendefinisikan kompetensi bahwa "a competency isan underlying characteristic's of an individual which is causally related to criterion referenced effective and/or superior performance in a job or situation".

Dalam penjelasan Pasal 3 Peraturan Pemerintah Nomor 101 Tahun 2000 tentang Pendidikan dan Pelatihan Jabatan Pegawai Negeri Sipil, yang dimaksud dengan kompetensi adalah kemampuan dan karakteristik yang dimiliki oleh seorang PNS berupa pengetahuan, keterampilan, dan sikap perilaku yang diperlukan dalam pelaksanaan tugas jabatannya. Ketiga karakteristik ini kemudian dijadikan pedoman dalam penyusunan standar kompetensi jabatan PNS, seperti dikemukakan oleh Prayitno (2003:11) standar kompetensi mencakup tiga hal, yang disingkat dengan KSA yaitu: (1) pengetahuan (knowledge), yaitu fakta dan angka di balik aspek teknis; (2) keterampilan (skills), yaitu kemampuan untuk menunjukkan tugas pada tingkat kriteria yang dapat diterima secara terus-menerus dengan kegiatan yang paling sedikit; (3) sikap (attitude), yaitu yang ditunjukkan kepada pelanggan dan orang lain bahwa yang bersangkutan mampu berada dalam lingkungan kerjanya.

Dalam pengelolaan keuangan daerah yang baik, SKPD harus memiliki sumber daya manusia yang berkualitas, yang didukung dengan latar belakang pendidikan akuntansi, sering mengikuti pendidikan dan pelatihan, dan mempunyai pengalaman di bidang keuangan. Sehingga untuk menerapkan sistem akuntansi, SDM yang berkualitas tersebut akan mampu memahami logika akuntansi dengan baik. Kegagalan SDM pemerintah daerah dalam memahami dan menerapkan logika akuntansi akan berdampak pada kekeliruan laporan keuangan yang dibuat dan ketidaksesuaian laporan dengan standar yang ditetapkan pemerintah.

\section{Teknologi Informasi}

Teknologi informasi menurut Martin, Brown, DeHayes, Hofer dan Perkins (2002:1) adalah teknologi komputer yang digunakan untuk mengirimkan informasi. Definisi teknologi informasi sangat luas dan mencakup semua bentuk teknologi yang digunakan dalam menangkap, manipulasi, mengkomunikasikan, menyajikan dan menggunakan data yang akan diubah menjadi informasi. Wilkinson et al.(2000:34) menyatakan bahwa "information technology includes computers (mainframes, mini, micro), software, databases, networks (internet, intranet), electric commerce, and other types of related technologies". Teknologi informasi selain sebagai teknologi komputer (hardware dan software) untuk memproses dan penyimpanan informasi juga berfungsi sebagai teknologi komunikasi untuk penyebaran 
informasi. Total volume Anggaran dan Pendapatan dan Belanja Negara/Daerah dari tahun ke tahun semakin meningkat. Dari sisi akuntansi hal itu menunjukkan bahwa volume transaksi keuangan pemerintah semakin besar dan semakin rumit juga kompleks. Oleh karena itu pemerintah berkewajiban untuk mengembangkan dan memanfaatkan kemajuan teknologi informasi untuk meningkatkan kemampuan dalam mengelola keuangan daerah. Pemanfaatan teknologi informasi yang meliputi teknologi komputer dan teknologi komunikasi dalam pengelolaan keuangan daerah akan meningkatkan pemrosesan transaksi dan data lainnya, keakurasian dalam perhitungan, serta penyiapan laporan dan output lainnya lebih tepat waktu.

\section{Reviu Laporan Keuangan}

Pengawasan intern berdasarkan Peraturan Pemerintah nomor 60 tahun 2008 pasal 1 ayat 3 adalah seluruh proses kegiatan audit, reviu, evaluasi, pemantauan, dan kegiatan pengawasan lain terhadap penyelenggaraan tugas dan fungsi organisasi dalam rangka memberikan keyakinan yang memadai bahwa kegiatan telah dilaksanakan sesuai dengan tolok ukur yang telah ditetapkan secara efektif dan efisien untuk kepentingan pimpinan dalam mewujudkan tata pemerintahan yang baik.

Kegiatan pengawasan yang dilakukan oleh APIP ada 5 (lima) jenis yaitu Pemeriksaan Reguler, Monitoring, Pemeriksaan Khusus, Evaluasi Laporan Kinerja Instansi Pemerintah, dan Reviu Laporan Keuangan Pemerintah Daerah.Dalam pasal 33 ayat (3) Peraturan Pemerintah Nomor 8 Tahun 2006 diatur bahwa Inspektorat Provinsi/Kabupaten/Kota melakukan reviu atas laporan keuangan dan kinerja dalam rangka memberikan keyakinan terbatas bahwa laporan keuangan disajikan telah sesuai dengan SAP. Selanjutnya dalam Peraturan Menteri Dalam Negeri No.4 Tahun 2008 tentang Pedoman Pelaksanaan Reviu atas LKPD Pasal 1 angka 9.

Reviu atas LKPD dilakukan untuk memberikan keyakinan atas kualitas laporan keuangan pemerintah daerah dengan ruang lingkup meliputi penilaian terbatas terhadap keandalan Sistem Pengendalian Intern dan kesesuaian dengan Standar Akuntansi Pemerintahan. Dengan kata lain Reviu LKPD untuk memberikan keyakinan terbatas bahwa laporan keuangan pemerintah daerah disusun berdasarkan sistem pengendalian intern yang memadai dan disajikan sesuai dengan standar akuntansi pemerintahan.

\section{Sistem Pengendalian Internal}

The Committe of Sponsoring Organization of the Treadway Commission (COSO) mendefinisikan pengendalian internal sebagai berikut.

Internal control is broadly defined as a process, effected by an entity's board of directors, management, and other personnel, designed to provide reasonable assurance regarding the achievement of objectives in the following categories: (1) Effectiveness and efficiency of operations; (2) Reliability of financial reporting; (3) Compliance with applicable laws and regulations.

COSO memperkenalkan adanya 5 (lima) unsur pengendalian internal yang meliputi lingkungan pengendalian (control environment), penaksiran risiko (risk assesment), aktivitas pengendalian (control activities), informasi dan komunikasi (information and communication), serta pemantauan (monitoring activities). Penjelasan mengenai unsur pengendalian internal tersebut seperti yang tertuang dalam Peraturan Pemerintah No. 60 Tahun 2008.

Dalam lampiran 1 Permendagri No. 4 Tahun 2008, bahwa kualitas laporan keuangan tidak hanya diukur dari kesesuaian dengan SAP saja, tetapi juga dari sistem pengendalian internnya. Untuk itu, pemerintah daerah harus mendesain, mengoperasikan, dan memelihara SPI yang baik dalam rangka menghasilkan informasi keuangan yang andal. 


\section{KERANGKA KONSEPTUAL}

Berdasarkan uraian latar belakang, rujukan teori, konsep dan sejumlah hasil penelitian yang dikemukakan sebelumnya, dapat digambarkan skema kerangka pikir dari penelitian ini sebagai berikut :

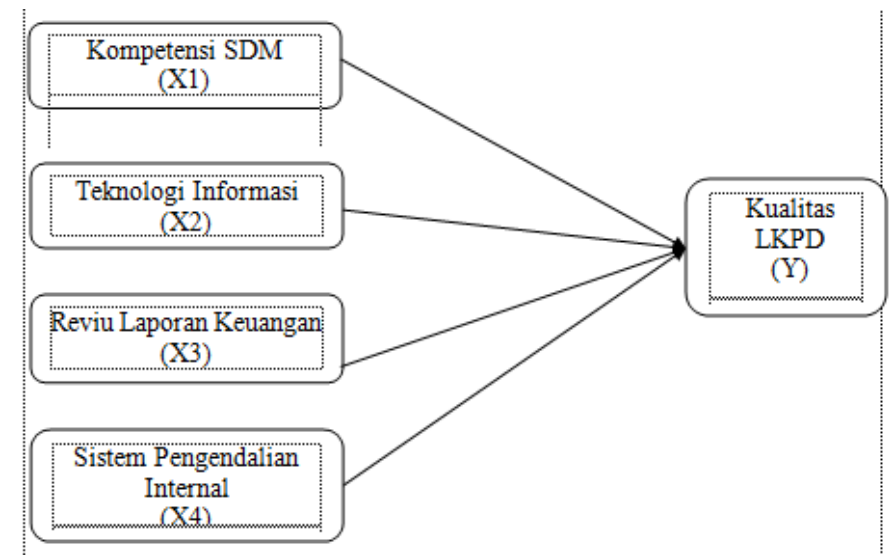

Gambar 3.1 Kerangka Konseptual Penelitian

Berdasarkan gambar 3.1 dapat dijelaskan bahwa variabel X1 kompetensi SDM, variabel X2 teknologi informasi, variabel X3 reviu laporan keuangan, dan variabel X4 sistem pengendalian internal berpengaruh terhadap variabel $\mathrm{Y}$ kualitas laporan keuangan pemerintah daerah provinsi Sulawesi Utara.

\section{Hipotesis Penelitian}

\section{Pengaruh Kompetensi SDM terhadap Kualitas Laporan Keuangan Pemerintah Daerah}

Kegagalan sumber daya manusia pemerintah daerah dalam memahami dan menerapkan logika akuntansi akan berdampak pada kekeliruan laporan keuangan yang dibuat dan ketidaksesuaian laporan dengan standar yang ditetapkan pemerintah. Sehingga untuk dapat menyajikan LKPD yang berkualitas diperlukan SDM yang memiliki kompetensi. Hal ini sejalan dengan hasil penelitian Evicahyani (2015) pada pemerintah daerah Subosukawonosraten menunjukkan bahwa sumber daya manusia berpengaruh signifikan terhadap keterandalan pelaporan keuangan pemerintah daerah. Hal ini disebabkan kondisi sub bagian akuntansi/tata usaha keuangan yang sudah mencukupi baik dari sisi jumlah maupun kualifikasinya, selain itu uraian tugas dan fungsi sub bagian akuntansi/tata usaha keuangan yang ada sudah terspesifikasi dengan jelas. Fungsi dan proses akuntansi dapat dilaksanakan oleh pegawai yang memiliki pengetahuan di bidang ilmu akuntansi.

\section{$\mathrm{Ha}_{1}$ : Kompetensi SDM berpengaruh positif terhadap kualitas laporan keuangan. Pengaruh Teknologi Informasiterhadap Kualitas Laporan Keuangan}

Dalam Penjelasan Peraturan Pemerintah No. 56 Tahun 2005 tentang Sistem Informasi Keuangan Daerah disebutkan bahwa untuk menindaklanjuti terselenggaranya proses pembangunan yang sejalan dengan prinsip tata kelola pemerintahan yang baik (good governance), pemerintah dan pemerintah daerah berkewajiban untuk mengembangkan dan memanfaatkan kemajuan teknologi informasi untuk meningkatkan kemampuan mengelola keuangan daerah dan menyalurkan informasi keuangan daerah kepada pelayanan publik.Pemerintah perlu mengoptimalisasi pemanfaatan kemajuan teknologi informasi untuk membangun jaringan sistem informasi manajemen dan proses kerja yang memungkinkan pemerintahan bekerja secara terpadu dengan menyederhanakan akses antar unit kerja.

Penelitian Zainani (2013) menunjukkan bahwa pemanfaatan teknologi informasi mempunyai pengaruh positif dan signifikan terhadap keterandalan dan ketepatwaktuan pelaporan keuangan pemerintah. Dengan menggunakan teknologi informasi maka informasi keuangan yang dihasilkan dapat lebih akurat jika dibandingkan dengan menggunakan proses 
manual sehingga laporan keuangan dapat disajikan tepat waktu dan andal (Sukirman, 2012). Sejalan dengan penelitian Pradono dan Basukianto (2014) yang menunjukkan bahwa teknologi informasi berpengaruh positif dan signifikan pada kualitas laporan keuangan pemerintah daerah.

$\mathrm{Ha}_{2}$ : Teknologi informasi berpengaruh positif terhadap kualitas laporan keuangan. Pengaruh Reviu Laporan Keuangan terhadap Kualitas Laporan Keuangan

Laporan Keuangan Pemerintah Daerah diaudit oleh BPK rangka memberikan pernyataan opini tentang tingkat kewajaran informasi yang disajikan dalam laporan keuangan pemerintah. Dalam pasal 33 ayat 3 Peraturan Pemerintah Nomor 8 Tahun 2006 tentang Pelaporan Keuangan dan Kinerja Instansi Pemerintah (PKKIP) diatur bahwa Inspektorat Provinsi/Kabupaten/Kota melakukan reviu atas laporan keuangan dan kinerja dalam rangka meyakinkan keandalan informasi yang disajikan sebelum disampaikan oleh Gubernur/Bupati/Walikota kepada Badan Pemeriksa Keuangan (BPK). Oleh karena itu, proses reviu menjadi krusial untuk dilaksanakan oleh Pemerintah Daerah dalam rangka melaksanakan amanah peraturan perundangan dan dalam rangka mewujudkan tata kelola yang lebih baik.

Penelitian Manaf dan Darwanis (2015) menunjukkan bahwa proses reviu laporan keuangan pemerintah daerah berpengaruh terhadap kualitas LKPD.

\section{Ha3: Reviu laporan keuangan berpengaruh positif terhadap kualitas laporan keuangan.}

\section{Pengaruh Sistem Pengendalian Internal Terhadap Kualitas Laporan Keuangan}

Sesuai dengan Peraturan Pemerintah Nomor 60 Tahun 2008 tentang Sistem Pengendalian Intern Pemerintah, tujuan SPIP adalah untuk memberikan keyakinan yang memadai bagi tercapainya efektivitas dan efisiensi pencapaian tujuan penyelenggaraan pemerintahan negara, keandalan pelaporan keuangan, pengamanan aset negara, dan ketaatan terhadap peraturan perundang-undangan. Selanjutnya dalam Peraturan Menteri Dalam Negeri nomor 4 tahun 2008 tentang Pedoman Pelaksanaan Reviu atas Laporan Keuangan Pemerintah Daerah menjelaskan bahwa kualitas laporan keuangan tidak hanya diukur dari kesesuaian dengan SAP saja, tetapi juga dari sistem pengendalian internnya. Untuk itu, pemerintah daerah harus mendesain, mengoperasikan, dan memelihara SPI yang baik dalam rangka menghasilkan informasi keuangan yang andal. Dengan mengoptimalkan SPIP diharapkan pengendalian intern semakin efektif sehingga dapat memediasi dalam mengatasi permasalahan rendahnya kualitas informasi keuangan.

Hasil penelitianMahaputra (2014), Afiah dan Rahmatika (2014) menunjukkan bahwa sistem pengendalian intern berpengaruh terhadap kualitas laporan keuangan. Peningkatan pengendalian intern akan diikuti oleh peningkatan kualitas informasi laporan keuangan (Herman, 2015).

\section{Ha: Sistem Pengendalian Internal berpengaruh positif terhadap kualitas laporan keuangan.}

\section{METODE PENELITIAN}

\section{Jenis Penelitian}

Penelitian ini menggunakan jenis penelitian kuantitatif. Berdasarkan hubungan antara variabel yang diteliti, maka penelitian ini merupakan penelitian asosiatif kausal yaitu hubungan yang bersifat sebab-akibat. Jadi penelitian ini akan menganalisis pengaruh variabel independen yaitu Komitmen SDM ( $\left.\mathrm{X}_{1}\right)$, Teknologi Informasi $\left(\mathrm{X}_{2}\right)$, Reviu Laporan Keuangan $\left(\mathrm{X}_{3}\right)$ dan Sistem Pengendalian Internal $\left(\mathrm{X}_{4}\right)$ terhadap variabel dependen yaitu Kualitas Laporan Keuangan Pemerintah Daerah (Y). 


\section{Sumber Data}

Data yang digunakan dalam penelitian ini adalah data primer. Data penelitian diperoleh melalui observasi dan kuesioner yang dilakukan dengan cara memberi pertanyaan tertulis kepada responden untuk dijawab.

\section{Populasi Sampel, Besar Sampel, dan Teknik Pengambilan Sampel}

Populasi dalam penelitian ini adalah seluruh pengelola keuangan di lingkungan Pemerintah Provinsi Sulawesi Utara. Pengambilan sampel menggunakan teknik purposive sampling yaitu penentuan sampel berdasarkan pertimbangan tertentu. Sampel dalam penelitian ini adalah PPK-SKPD, bendahara dan staf PPK-SKPD fungsi akuntansi pada 47 Satuan Kerja Perangkat Daerah (SKPD) yang ada di lingkungan Pemerintah Provinsi Sulawesi Utara, sehingga sampel berjumlah 141 orang

\section{Lokasi dan Waktu Penelitian}

Objek dalam penelitian ini mengambil lokasi di Satuan Kerja Perangkat Daerah di lingkungan Pemerintah Provinsi Sulawesi Utara dengan waktu penelitian selama 3 (tiga) bulan yaitu mulai bulan Juni sampai dengan bulan Agustus 2016.

\section{Definisi Operasional dan Pengukuran Variabel}

Penelitian ini akan menggunakan 4 (empat) variabel independen, yaitu kompetensi SDM $\left(X_{1}\right)$, teknologi informasi $\left(X_{2}\right)$, reviu laporan keuangan $\left(X_{3}\right)$, dan sistem pengendalian internal $\left(\mathrm{X}_{4}\right)$, serta 1 (satu) variabel dependen yaitu Kualitas Laporan Keuangan (Y). Masingmasing variabel diukur dengan model skala Likert lima poin, yaitu (1) Sangat Tidak Setuju, (2) Tidak Setuju, (3) Netral, (4) Setuju, dan (5) Sangat Setuju. Responden diminta untuk menyatakan setuju atau ketidaksetujuannya terhadap pertanyaan yang diajukan sesuai dengan kondisi yang sesungguhnya.

\section{Kompetensi SDM}

Kompetensi SDM yang dimaksud dalam penelitian ini adalah karakteristik yang dimiliki pengelola keuangan dalam melaksanakan tugas penatausahaan keuangan (akuntansi) untuk menghasilkan laporan keuangan.

\section{Teknologi Informasi}

Variabel teknologi informasi dalam penelitian ini adalah pemanfaatan teknologi informasi oleh pengelola keuangan dengan mengkombinasikan alat perangkat komputer dengan telekomunikasi dalam proses penyusunan laporan keuangan, mulai dari pemrosesan, pengolahan dan penyebaran data. (Jurnali dan Supomo, 2002).

\section{Reviu Laporan Keuangan}

Reviu laporan keuangan dalam penelitian ini adalah reviu atas laporan keuangan pemerintah daerah yang dilakukan oleh Inspektorat, di dalamnya terdapat prosedur penelusuran angka-angka, permintaan keterangan dan analitas yang harus menjadi dasar memadai bagi Inspektorat untuk memberi keyakinan terbatas atas laporan keuangan bahwa tidak ada modifikasi material yang harus dilakukan atas laporan keuangan agar laporan keuangan tersebut disajikan berdasarkan Sistem Pengendalian Intern (SPI) yang memadai dan sesuai dengan Standar Akuntansi Pemerintah (SAP).

\section{Sistem Pengendalian Internal}

Sistem pengendalian internal adalah suatu proses integral pada tindakan dan kegiatan yang dilakukan oleh pimpinan dan seluruh pegawai untuk memberikan keyakinan memadai atas terciptanya tujuan organisasi melalui kegiatan yang efektif dan efisien, keandalan laporan keuangan, pengamanan aset negara, dan ketaatan terhadap peraturan perundangundangan.

\section{Kualitas Laporan Keuangan}

Kualitas laporan keuangan adalahkarakteristik kualitatif yang dimiliki oleh Laporan Keuangan Pemerintah Daerah atau persyaratan normatif dalam penyajian laporan keuangan pemerintah daerah sehingga dapat memenuhi kualitas yang dikehendaki. 


\section{Instrumen Penelitian}

\section{Uji Validitas}

Hasil penelitian yang valid bila terdapat kesamaan antara data yang terkumpul dengan data yang sesungguhnya terjadi pada obyek yang diteliti.

\section{Uji Reliabilitas}

Menurut Ghozali (2006:41) uji reliabilitas dimaksudkan untuk menguji konsistensi kuesioner jika digunakan dari waktu ke waktu. Uji reliabilitas dilakukan dengan cara menghitung koefisiencronbach alpha dari masing-masing instrumen dalam suatu variabel.

\section{Prosedur Pengambilan atau Pengumpulan Data}

Dalam usaha untuk memperoleh data dan informasi yang berkenaan dengan penelitian ini, serta sebagai bahan dan materi untuk keperluan dan pembahasan maka metode pengumpulan data yang diperoleh meliputi: (1) Survei Pendahuluan; (2) Survei Lapangan.

\section{Cara Pengolahan dan Analisis Data}

\section{Uji Asumsi Klasik}

Sebelum data dianalisis lebih lanjut menggunakan analisis regresi berganda, terlebih dahulu dilakukan uji asumsi klasik yang terdiri dari Uji Normalitas, Uji Multikolinieritas dan Uji Heterokedastisitas.

\section{Pengujian Hipotesis}

Hipotesis yang diajukan dalam penelitian ini adalah untuk menemukan apakah adapengaruh kompetensi SDM, teknologi informasi, reviu laporan keuangan, dan sistem pengendalian internal terhadap kualitas laporan keuangan dengan uji statistik melalui, (1) Uji bersama-sama (Uji F); (2) Uji parsial (Uji t); (3) Uji koefisien korelasi dan koefisien determinasi. Untuk menguji hipotesis dalam penelitian ini digunakan metode statistik regresi berganda (MultipleRegression) dengan persamaan sebagai berikut :

Fungsi Regresi Berganda :

$$
\mathbf{Y}=\alpha+\beta_{1} X_{1}+\beta_{2} X_{2}+\beta_{3} X_{3}+\beta_{4} X_{4}+e
$$

\section{HASIL PENELITIAN}

\section{Regresi Berganda}

Model regresi berganda dalam penelitian ini adalah untuk menguji pengaruh kompetensi SDM $\left(\mathrm{X}_{1}\right)$, teknologi informasi $\left(\mathrm{X}_{2}\right)$, reviu laporan keuangan $\left(\mathrm{X}_{3}\right)$, dan sistem pengendalian internal $\left(\mathrm{X}_{4}\right)$ terhadap kualitas laporan keuangan $(\mathrm{Y})$. Hasil analisis regresi berganda dapat dilihat pada tabel 5.16.

Tabel 1 Hasil Regresi Berganda Coefficientsa

\begin{tabular}{|c|c|c|c|c|c|c|}
\hline \multirow{2}{*}{\multicolumn{2}{|c|}{ Model }} & \multicolumn{2}{|c|}{ Unstandardized Coefficients } & $\begin{array}{c}\text { Standardized } \\
\text { Coefficients }\end{array}$ & \multirow[b]{2}{*}{$\mathrm{T}$} & \multirow[b]{2}{*}{ Sig. } \\
\hline & & B & Std. Error & Beta & & \\
\hline \multirow[t]{5}{*}{1} & (Constant) & 2.018 & 3.093 & & .653 & .516 \\
\hline & $\mathrm{x} 1$ & .145 & .089 & .155 & 1.628 & .107 \\
\hline & $x 2$ & .225 & .111 & .151 & 2.035 & .045 \\
\hline & $x 3$ & .185 & .082 & .180 & 2.268 & .026 \\
\hline & $\mathrm{x} 4$ & .501 & .106 & .479 & 4.713 & .000 \\
\hline
\end{tabular}

a. Dependent Variable: $y$

Sumber: Hasil olah data dengan SPSS

Berdasarkan tabel 1, diperoleh persamaan regresi berganda sebagai berikut :

$$
\begin{gathered}
Y=\alpha+\beta_{1} X_{1}+\beta_{2} X_{2}+\beta_{3} X_{3}+\beta_{4} X_{4}+e \\
Y=2,018+0,145 X_{1}+0,225 X_{2}+0,185 X_{3}+0,501 X_{4}+e
\end{gathered}
$$

Dengan interpretasi bahwa : 
Nilai konstanta $(\alpha)$ sebesar 2,018 menunjukkan kualitas laporan keuangan (Y) mempunyai hubungan positif atau searah dengan kompetensi SDM (X1), teknologi informasi (X2), reviu laporan keuangan (X3) dan sistem pengendalian internal (X4).Variabel kompetensi SDM (X1) memiliki nilai koefisien regresi $(\beta)$ sebesar 0,145 dan bernilai positf, menunjukkan bahwa kompetensi SDM memiliki pengaruh positif terhadap kualitas laporan keuangan, artinya apabila variabel lain nilainya tetap atau tidak berubah, maka setiap peningkatan kompetensi SDM akan menambah kualitas laporan keuangan (Y). Variabel teknologi informasi (X2) memiliki nilai koefisien regresi ( $\beta$ ) sebesar 0,225 dan bernilai positf, menunjukkan bahwa teknologi informasi memiliki pengaruh positif terhadap kualitas laporan keuangan, artinya setiap adanya peningkatan dalam teknologi informasi maka akan mengakibatkan peningkatan dalam kualitas laporan keuangan $(\mathrm{Y})$ dengan asumsi faktor lain konstan. Variabel reviu laporan keuangan (X3) memiliki nilai koefisien regresi ( $\beta$ ) sebesar 0,185 dan bernilai positf, menunjukkan bahwa reviu laporan keuangan memiliki pengaruh positif terhadap kualitas laporan keuangan, artinya setiap adanya peningkatan dalam reviu laporan keuangan maka akan mengakibatkan peningkatan dalam kualitas laporan keuangan (Y) dengan asumsi faktor lain konstan. Variabel sistem pengendalian internal (X4) memiliki nilai koefisien regresi $(\beta)$ sebesar 0,501 dan bernilai positf, menunjukkan bahwa sistem pengendalian internal memiliki pengaruh positif terhadap kualitas laporan keuangan, artinya setiap adanya peningkatan dalam sistem pengendalian internal maka akan mengakibatkan peningkatan dalam kualitas laporan keuangan (Y) dengan asumsi faktor lain konstan.

\section{Pembahasan}

\section{Pengaruh kompetensi SDM terhadap kualitas laporan keuangan.}

Hasil pengujian hipotesis pertama menunjukkan bahwa pada kompetensi $\mathrm{SDMt}_{\text {hitung }}$ $=1,628<\mathrm{t}_{\text {tabel }}=1,98667$ sehingga kompetensi $\mathrm{SDM}$ tidak berpengaruh signifikan terhadap kualitas laporan keuangan. Dalam pencapaian efektivitas pengelolaan keuangan, pemerintah harus memiliki sumber daya manusia yang berkompeten. Menurut Bastian (2006:55) bahwa penyiapan dan penyusunan laporan keuangan yang berkualitas memerlukan SDM yang menguasai akuntansi pemerintahan.Kompetensi SDM merupakan variabel penentu dalam meningkatkan kualitas LKPD (Sudriarianti, 2015). Kompetensi yang dimiliki seorang PNS meliputi pengetahuan, keterampilan dan sikap perilaku (PP no.101 tahun 2000).Berdasarkan data yang diperoleh, pengelolaan SDM pengelola keuangan pada Pemerintah Provinsi Sulawesi Utara belum optimal. Hal ini ditandai dengan jumlah dan kompetensi SDM pengelola keuangan yang belum sesuai dengan kebutuhan. Di samping itu SDM pengelola keuangan belum memiliki pemahaman yang memadai tentang pengelolaan keuangan khususnya penyusunan laporan keuangan. Hal ini disebabkan karena walaupun berbagai pelatihan maupun sosialisasi telah dilakukan namun pengelola keuangan yang telah mengikuti pelatihan dan sosialisasi telah dimutasi. Dari data demografi responden didapati SDM yang menempati posisi pengelola keuangan masih tergolong baru dan responden yang berlatar belakang pendidikan akuntansi hanya sebesar $15 \%$. Hal ini menyebabkan variabel kompetensi SDM dalam penelitian ini tidak berpengaruh signifikan terhadap kualitas laporan keuangan. Selain itu, dalam proses penyusunan laporan keuangan telah didukung dengan teknologi informasi yang ada yang berfungsi untuk membantu kelancaran penyusunan laporan keuangan sehingga pengelola keuangan di SKPD yang bertugas membuat laporan keuangan SKPD tidak harus mempunyai pengetahuan yang memadai tentang siklus akuntansi karena proses akuntansi seluruhnya telah dikerjakan oleh SIMDA, SDM dalam hal ini hanya menginput data saja.Kondisi ini menyebabkan penyusunan laporan keuangan SKPD yang merupakan tanggung jawab SKPD sebagai entitas akuntansi tidak sepenuhnya terlaksana karena sebagian dikerjakan oleh SKPD, padahal SKPD adalah unit organisasi yang mandiri dan mempunyai kewajiban menyajikan laporan keuangan sehingga tidak terjadi kekacauan 
untuk menyajikan laporan keuangan antar unit instansi pemerintah dalam pelaporan keuangan (PP 71/2010).

Hasil penelitian ini mendukung penelitian yang dilakukan Syarifudin (2014) pada Pemerintah Kabupaten Kebumen, di mana kompetensi SDM tidak berpengaruh signifikan terhadap kualitas LKPD, dalam arti meningkatnya variasi kompetensi tidak berpengaruh signifikan terhadap peningkatan kualitas LKPD. Demikian juga hasil penelitian dari Winidyaninrum dan Rachmawati (2010) pada Pemerintah Daerah Surakarta, Boyolali, Sukoharjo, Karanganyar, Wonogiri, Sragen dan Klaten (Subosukawonosraten), yang menunjukkan bahwa SDM berpengaruh tidak signifikan terhadap ketepatwaktuan pelaporan keuangan pemerintah daerah.

Hasil penelitian ini tidak sejalan dengan hasil penelitian Pradono dan Basukianto (2015) pada SKPD Pemerintah Provinsi Jawa Tengah yang menunjukkan bahwa semakin baik kompetensi sumber daya manusia maka semakin baik kualitas laporan keuangan SKPD. Demikian pula penelitian yang dilakukan Mahaputra dan Wayan Putra (2014), Winidyaningrum dan Rachmawati (2010),Evicahyani (2015), Zainani (2013) danSudriarianti (2014) menunjukkan hasilyang menyatakan bahwa kompetensi SDM berpengaruh positif pada kualitas laporan keuangan pemerintah daerah.

5.1.1 Pengaruh teknologi informasi terhadap kualitas laporan keuangan.

Hasil pengujian hipotesis kedua menunjukkan bahwa pada teknologi informasi $t_{\text {hitung }}$ $=2,035>t_{\text {tabel }}=1,98667$ sehingga teknologi informasi berpengaruh secara signifikan terhadap kualitas laporan keuangan. Nilai koefisien regresi teknologi informasi sebesar 0,225menunjukkan bahwa penambahan satu satuan teknologi informasi akan menambah kualitas laporan keuangan sebesar 0,225 satuan.

Hasil penelitian ini mendukung literatur yang berkaitan dengan manfaat dari suatu teknologi informasi dalam organisasi, termasuk pemerintah daerah yang harus mengelola APBD dengan volume transaksi yang semakin meningkat dan kompleks. Penggunaan teknologi yang andal diperlukan untuk mendukung keberhasilan pengolahan data. Pemerintah Provinsi Sulawesi Utara telah memanfaatkan teknologi informasi seperti komputer, jaringan internet dan softwareakuntansi berupa Sistem Informasi Manajemen Daerah (SIMDA) sehingga memudahkan pegawai pengelola keuangan dalam menyusun laporan keuangan. Dengan menggunakan teknologi informasi tersebut informasi keuangan yang dihasilkan dapat lebih akurat dan disajikan tepat waktu.

Hal ini sejalan dengan hasil penelitian Zainani (2013) pada Kabupaten Pesaweran yang menyatakan bahwa pemanfaatan teknologi informasi berpengaruh secara positif dan signifikan terhadap keterandalan dan ketepatwaktuan pelaporan keuangan Pemerintah Daerah. Selain itu mendukung juga hasil penelitian dari Winidyaningrum dan Rahmawati (2010) yang membuktikan bahwa pemanfaatan teknologi informasi mempunyai pengaruh yang signifikan terhadap keterandalan pelaporan keuangan pemerintah daerah.

\section{Pengaruh reviu laporan keuangan terhadap kualitas laporan keuangan.}

Hasil pengujian hipotesis ketiga menunjukkan bahwa padareviu laporan keuangan, $\mathrm{t}_{\text {hitung }}=2,268>\mathrm{t}_{\text {tabel }}=1,98667$ sehinggareviu laporan keuangan berpengaruh secara signifikan terhadap kualitas laporan keuangan. Nilai koefisien regresi reviu laporan keuangan sebesar 0,185 menunjukkan bahwa penambahan satu satuan reviu laporan keuangan akan menambahkualitas laporan keuangan sebesar 0,185 satuan.

Hasil penelitian ini mendukung penelitian Manaf (2014) pada kabupaten kota di Provinsi Aceh yang menunjukkan bahwa reviu laporan keuangan pemerintah daerah mempunyai pengaruh signifikan terhadap kualitas laporan keuangan pemerintah daerah. Artinya tinggi rendahnya kualitas laporan keuangan dipengaruhi oleh proses reviu LKPD oleh inspektorat. Selain itu penelitian Herman (2015) menunjukkan bahwa audit internal yang dilaksanakan oleh auditor berpengaruh terhadap kualitas informasi laporan keuangan 
kabupaten Jeneponto. Auditor internal menjalankan fungsinya menelaah informasi laporan keuangan untuk mendapatkan laporan keuangan yang berkualitas. Kegiatan audit internal termasuk di dalamnya reviu laporan keuangan.

Hal ini sejalan dengan Peraturan Menteri Dalam Negeri No.4 tahun 2008 bahwa reviu atas laporan keuangan pemerintah daerah dilakukan untuk memberikan keyakinan atas kualitas laporan keuangan pemerintah daerah dengan ruang lingkup meliputi penilaian terbatas terhadap keandalan SPI dan kesesuaian dengan SAP. Aparat pengawas intern pemerintah dalam hal ini inspektorat melakukan reviu dengan berpedoman pada prosedur reviu atas LKPD yang terdiri dari perencanaan, pelaksanaan, dan pelaporan. Melalui rangkaian prosedur reviu diharapkan dapat memberikan keyakinan bahwa laporan keuangan pemerintah daerah telah disajikan berdasarkan SPI yang memadai dan sesuai dengan SAP.

Pengaruh sistem pengendalian internal terhadap kualitas laporan keuangan.

Hasil pengujian hipotesis ketiga menunjukkan bahwa padasistem pengendalian internal, $\mathrm{t}_{\text {hitung }}=4,713>\mathrm{t}_{\text {tabel }}=1,98667$ sehinggasistem pengendalian internal berpengaruh secara signifikan terhadap kualitas laporan keuangan. Nilai koefisien regresi sistem pengendalian internal sebesar 0,501 menunjukkan bahwa penambahan satu satuan sistem pengendalian internal akan menambah kualitas laporan keuangan sebesar 0,501 satuan.

Dalam Peraturan Pemerintah Republik Indonesia Nomor 60 tahun 2008 disebutkan bahwa SPIP bertujuan untuk memberikan keyakinan memadai bagi tercapainya efektivitas dan efisiensi pencapaian tujuan penyelenggaraan pemerintahan negara, keandalan pelaporan keuangan, pengamanan aset negara, dan ketaatan terhadap peraturan perundang-undangan. Selain itu dalam Peraturan Menteri Dalam Negeri tahun 2008 lampiran I menyebutkan bahwa kualitas laporan keuangan tidak hanya diukur dari kesesuaian dengan SAP saja, tetapi juga dari sistem pengendalian internnya. Untuk itu pemerintah daerah harus mendesain, mengoperasikan, dan memelihara SPI yang baik dalam rangka menghasilkan informasi keuangan yang andal. Dengan adanya pengendalian intern yang efektif dapat meminimalisir risiko kesalahan dalam penyusunan dan penyajian laporan keuangan.

Hasil peneltian ini mendukung hasil penelitian Pradono dan Basukianto (2015), Sudriarianti (2014) dan Syarifudin (2014) yang menunjukkan bahwa sistem pengendalian intern berpengaruh signifikan terhadap kualitas LKPD, artinya semakin efektif sistem pengendalian intern maka semakin baik kualitas LKPD.

\section{KESIMPULAN DAN SARAN Kesimpulan}

Tujuan dari penelitian ini adalah untuk mengetahui apakah kompetensi SDM, teknologi informasi, reviu laporan keuangan, dan sistem pengendalian internal berpengaruh terhadap kualitas laporan keuangan pada Pemerintah Provinsi Sulawesi Utara, baik secara parsial maupun secara simultan.Dari hasil penelitian disimpulkan bahwa :

1) Dari hasil uji t atau secara parsial, dapat disimpulkan bahwa variabel Kompetensi SDM (X1) tidak berpengaruhsecara signifikan terhadap kualitas LKPD (Y) pada Pemerintah Provinsi Sulawesi Utara;

2) Variabel teknologi informasi (X2) berpengaruh secara signifikan terhadap kualitas LKPD (Y) pada Pemerintah Provinsi Sulawesi Utara;

3) Variabel reviu laporan keuangan (X3) berpengaruhsecara signifikan terhadapkualitas LKPD (Y) pada Pemerintah Provinsi Sulawesi Utara;

4) Variabel sistem pengendalian internal (X4) berpengaruh secara signifikan terhadap kualitas laporan keuangan (Y) pada Pemerintah Provinsi Sulawesi Utara;

5) Dari hasil uji $\mathrm{f}$ atau secara simultan, dapat disimpulkan bahwa variabel Kompetensi SDM (X1), teknologi informasi (X2), reviu laporan keuangan (X3) dan sistem 
pengendalian internal (X4)secara bersama-sama berpengaruh secara signifikan terhadap kualitas laporan keuangan (Y) pada Pemerintah Provinsi Sulawesi Utara;

\section{Saran}

Saran untuk penelitian berikutnya:

a. Bagi peneliti selanjutnya diharapkan dapat memperluas sampel penelitian, dengan mengambil sampel pada kabupaten dan kota yang ada di Provinsi Sulawesi Utara sehingga hasilnya dapat digeneralisasi.

b. Peneliti selanjutnya diharapkan dapat menambah variabel independen lain yang belum diteliti pada penelitian ini agar dapat mengetahui faktor-faktor lain yang mungkin mempengaruhi kualitas laporan keuangan pemerintah daerah.

c. Peneliti selanjutnya dapat mempertimbangkan menggunakan metode metode campuran kuantitatif dan kualitatif dalam penelitian, dimana metode kualitatif digunakan untuk menjelaskan hasil yang diperoleh dari metode kuantitatif sehingga dapat memperoleh kesimpulan yang sesuai dengan kondisi sebenarnya.

\section{DAFTAR PUSTAKA}

Afiah, Nunuy Nur and D. N. Rahmatika. 2014. Factors Influencing the Quality of Financial Reporting and its Implications on Good Government Governance. International Journal of Business, Economics and Law, Vol.5. Issue 1 December. p.111-121. ISSN 2289-1552.

Badan Pemeriksa Keuangan Perwakilan Provinsi Sulawesi Utara, 2015. Laporan Hasil Pemeriksaan Kinerja atas Efektivitas Upaya Pemerintah Daerah dalam Implementasi Standar Akuntansi Pemerintahan Berbasis Akrual Tahun 2014 dan 2015 (s.d Triwulan III) pada Pemerintah Provinsi Sulawesi Utara.

Badan Pemeriksa Keuangan Republik Indonesia, 2016. Ikhtisar Hasil Pemeriksaan Semester II Tahun 2015. Jakarta.

Bastian, I. 2006. Akuntansi Sektor Publik: Suatu Pengantar. Jakarta: Erlangga.

Bungin, Burhan. 2014. Metodologi Penelitian Kuantitatif. Jakarta : Kencana Prenada Media Group.

Committe of Sponsoring Organizations of the Treadway Commision (COSO), 1994. Internal Control-Integrated Framework. AICPA Publication.

Darmawati, Khomsiyah dan R. G. Rahayu. (2005). Hubungan Corporate Governance dan Kinerja Perusahaan. Jurnal Riset Akuntansi Indonesia. Yogyakarta. Vol. 8, No. 1. Hal. 65-81.

Djalil, Rizal. 2014. Akuntabilitas Keuangan Daerah: Implementasi Pasca Reformasi. Jakarta : RMBOOKS.

Evicahyani, Sagung Inten. 2015. Analisis Faktor-faktor yang Mempengaruhi Kualitas Laporan Keuangan Pemerintah Daerah Kabupaten Tabanan. Tesis. Program Pascasarjana Universitas Udayana Denpasar.

Ghozali, I. 2006. Aplikasi Analisis Multivariate Dengan Program SPSS. Cetakan Keempat. Semarang: Badan Penerbit Universitas Diponegoro.

Goodhue and Thompson. 1995. Task-Technology Fit and Individual Performance. MIS Quarterly, Juni. 213-236.

Governmental Accounting Standard Board (GASB). 1999. Concepts Statement No.1:Objective of Financial Reporting.

Guy, Dan M., Alderman, C. Wayne dan Winters, Alan J. 2002. Auditing:Jilid 1. Jakarta:Erlangga.

Herman. 2015. Pengaruh Komitmen Organisasi dan Audit Internal Terhadap Kualitas Informasi Laporan Keuangan: Pengendalian Intern sebagai Variabel Intervening. Tesis. Program Magister Akuntansi Universitas Hasanuddin Makassar. 
Hilton, R. W., Michael, W. M. and Frank, H. S. 2000. Cost Management, Strategies for Business Decision. International Edition. McGraw-Hill Companies, Inc.

Indriasih, Dewi dan P. S. Koeswayo. 2014. The Effect of Government Apparatus Competence and the Effectiveness of Government Internal Control toward the Quality of Financial Reporting and its Impact on the Performance Accountability in Local Government. South East Asia Journal of Contemporary Business, Economics and Law, Vol.5. Issue 1 December. p.90-100. ISSN 2289-1560.

Ikatan Akuntan Indonesia. 2012. Standar Akuntansi Keuangan.PSAK. Cetakan Keempat. Buku Satu. Jakarta : Penerbit Salemba Empat

Jensen, M. and Mecking, W. 1976. Theory of The Firm : Managerial Behaviour, Agency Costs and Ownership Stucture. Journal of Financial Economics 3 (4).

Jurnali, Teddy dan Bambang Supomo. 2002. Pengaruh Faktor-faktor Kesesuaian Tugas Teknologi dan Pemanfaatan Teknologi Informasi terhadap Kinerja Akuntan Publik. Jurnal Riset Akuntansi Indonesia Vol.5 No.2, Hal.214-228.

Kadir, Abdul. 2014. Pengenalan Sistem Informasi. Edisi Revisi. Yogyakarta : Penerbit Andi.

Kesuma, I, Nadirsyah, Darwanis. 2014. Pengaruh kompetensi sumber daya manusia, peran internal auditor dan aktivitas pengendalian terhadap nilai informasi pelaporan keuangan pemerintah daerah (studi pada pemerintah kabupaten Aceh Utara). Jurnal.

Kotler, Philip. 2005. Management Pemasaran. Jilid 1 dan 2. Edisi Kesebelas. Alih Bahasa Benyamin Molan. Jakarta : Indeks.

Laudon, K. C., Jane P. Laudon. 2006. Management Information System. 9th edition. New Jersey : Prentice-Hall, Inc

Lane, Jan-Erik. 2003. Management and Public Organization : The principal-agent framework. University of Geneva and National University of Singapore. Working paper.

Mahaputra, I.P.U.R dan I.W. Putra. 2014. Analisis Faktor-faktor yang Memengaruhi Kualitas Informasi Pelaporan Keuangan Pemerintah Daerah. Jurnal Akuntansi Universitas Udayana, Vol.8. No.2, Hal.230-244. ISSN 2302-8556.

Manaf, I. A., M. Arfan, dan Darwanis. 2014. Pengaruh Pemahaman tentang Standar Akuntansi Pemerintahan dan Sistem Pengendalian Intern terhadap Proses Reviu Laporan Keuangan Pemerintah Daerah oleh Inspektorat dan Implikasinya terhadap Kualitas Laporan Keuangan Pemerintah Daerah pada Inspektorat Kabupaten/Kota di Provinsi Aceh. Jurnal Magister Akuntansi Pascasarjana Universitas Syiah Kuala, Vol.3. No.4. November 2014, Hal.23-35. ISSN 2302-0164.

Mardiasmo. 2009. Akuntansi Sektor Publik. Yogyakarta : Penerbit Andi.

Martin, E. W., C. W. Brown, D. W. DeHayes, J. A. Hofer, dan W. C. Perkins. 2002. Managing Information Technology. New Jersey : Prentice-Hall, Inc.

Nuryanto, Muhamad and N. N. Afiah. 2013. The Impact of Apparatus Competence, Information Technology Utilization and Internal Control on Financial Statement Quality (Study on Local Government of Jakarta Province-Indonesia). World Review of Business Research, Vol.3. No.4. November. p.157-171.

Pangkong, Terry Corie. 2013. Faktor-faktor yang Mempengaruhi Kemampuan Penyusunan Laporan Keuangan Pemerintah Daerah di Kabupaten Biak Numfor. Tesis. Program Magister Akuntansi Universitas Sam Ratulangi Manado.

Peraturan Menteri Dalam Negeri Republik Indonesia Nomor 13 tahun 2006 tentang Pedoman Pengelolaan Keuangan Daerah.

Peraturan Menteri Dalam Negeri Republik Indonesia Nomor 23 tahun 2007 tentang Pedoman Tata Cara Pengawasan Atas Penyelenggaraan Pemerintahan Daerah.

Peraturan Menteri Dalam Negeri Republik Indonesia Nomor 4 tahun 2008 tentang Pedoman Pelaksanaan Reviu atas Laporan Keuangan Pemerintah Daerah. 
Peraturan Menteri Dalam Negeri Republik Indonesia Nomor 64 tahun 2013 tentang Pedoman Penerapan Standar Akuntansi Pemerintah Berbasis Akrual pada Pemerintah Daerah.

Peraturan Pemerintah Republik Indonesia Nomor 101 tahun 2000 tentang Pendidikan dan Pelatihan Jabatan Pegawai Negeri Sipil.

Peraturan Pemerintah Republik Indonesia Nomor 79 tahun 2005 tentang Pedoman Pembinaan dan Pengawasan Penyelenggaraan Pemerintahan Daerah.

Peraturan Pemerintah Republik Indonesia Nomor 8 tahun 2006 tentang Pelaporan Keuangan dan Kinerja Instansi Pemerintah.

Peraturan Pemerintah Republik Indonesia Nomor 60 tahun 2008 tentang Sistem Pengendalian Intern Pemerintah.

Peraturan Pemerintah Republik Indonesia Nomor 71 tahun 2010 tentang Standar Akuntansi Pemerintahan.

Pradono, F. C. dan Basukiato. 2015. Kualitas Laporan Keuangan Pemerintah Daerah: Faktor yang Mempengaruhi dan Implikasi Kebijakan (Studi pada SKPD Pemerintah Jawa Tengah). Jurnal Bisnis dan Ekonomi, Vol.22. No.2 September 2015, Hal.188200. ISSN 1412-3126.

Prasetyo, Agus dan S. Pangemanan. 2012. Analisis Dampak Reviu Inspektorat terhadap Kualitas Akuntabilitas Laporan Keuangan (LKPD) Kabupaten Minahasa Tenggara TA 2010 dan 2011. Jurnal.

Prayitno, Tim Peneliti BKN. 2003. Pedoman Penyusunan Standar Kompetensi Jabatan Pegawai Negeri Sipil. Puslitbang BKN, Jakarta.

Renkas, Jurij, O. Goncharenko and O. Lukianets. 2016. Quality of Financial Reporting:Approach to Measuring. International Journal of Accounting and Economics Studies, Vol.4(1). p.1-5.

Riyanto dan P. Agus. 2015. Akuntansi Pemerintah Daerah Berbasis Akrual. Yogyakarta : Pustaka Pelajar.

Ross, S.A, Westerfield, R.W \& Jaffe. 2010. Corporate Finance. (6th Edition). McGraw-Hill, Inc. USA.

Ruky, Achmad. 2003. Sumber Daya Berkualitas : Mengubah Visi menjadi realitas. Jakarta : Gramedia Pustaka Utama

Spencer, L. and S. Spencer. 1993. Competence At Work: Models for Superior Performance. Canada : John Wiley \& Sons, Inc.

Sudiarianti, Ni Made. 2015. Pengaruh Kompetensi Sumber Daya Manusia pada Penerapan Sistem Pengendalian Intern Pemerintah dan Standar Akuntansi Pemerintah serta Implikasinya pada Kualitas Laporan Keuangan Pemerintah. Tesis. Program Pascasarjana Universitas Udayana Denpasar.

Sugiyono. 2014. Metode Penelitian Kuantitatif, Kualitatif, Dan R\&D. Bandung: Alfabeta.

Sugiyono. 2015. Metode Penelitian Kuantitatif, Kualitatif, dan Kombinasi (Mixed Methods). Bandung : Alfabeta.

Sukirman, H. Sularso dan E. S. Nugraheni. 2012. Faktor-faktor yang Mempengaruhi Keterandalan dan Ketepatwaktuan Pelaporan Keuangan dengan Pengendalian Intern Akuntansi sebagai Variabel Pemoderasi (Studi Empiris pada Pemerintah Daerah Kabupaten Banyumas). Jurnal.

Suwanda, Dadang. 2015. Factors Affecting Quality of Local Government Financial Statement to Get Unqualified Opinion (WTP) of Audit Board of the Republic of Indonesia $(B P K)$. Research Journal of Finance and Accounting, Vol.6. No.4. p.139-157. ISSN 2222-1697.

Syarifudin, Akhmad. 2014. Pengaruh Kompetensi SDM dan Peran Audit Intern terhadap Kualitas Laporan Keuangan Pemerintah Daerah dengan Variabel Intervening Sistem 
Pengendalian Internal Pemerintah (studi empiris pada Pemkab Kebumen). Jurnal Fokus Bisnis, Vol.14. No.02 Desember 2014, Hal.26-44.

Undang-Undang Republik Indonesia Nomor 17 tahun 2003 tentang Keuangan Negara.

Undang-Undang Republik Indonesia Nomor 1 tahun 2004 tentang Perbendaharaan Negara.

Undang-Undang Republik Indonesia Nomor 15 tahun 2004 tentang Pemeriksaan Pengelolaan dan Tanggungjawab Keuangan Negara.

Undang-Undang Republik Indonesia Nomor 33 tahun 2004 tentang Perimbangan Keuangan Antara Pemerintah Pusat dan Pemerintah Daerah.

Undang-Undang Republik Indonesia Nomor 23 tahun 2014 tentang Pemerintah Daerah.

Warongan, J. D. L. 2015. Determinan Efektivitas Pengendalian Internal dan Pengaruhnya terhadap Kualitas Laporan Keuangan Pemerintah Daerah di Sulawesi Utara. Disertasi. Program Doktor Ilmu Ekonomi dan Bisnis Universitas Hasanuddin Makassar.

Warongan, J. D. L., G. Pagalung, and A. H. Habbe. 2014. The Effect of Effectiveness Mediation of Internal Control System on Competency of Human Resources and Audit Opinion in Previous Year towards Quality of Financial Statement. Journal of Research in Business and Management, Vol.2. Issue 11. p.09-16. ISSN 2347-3002.

Wilkinson, J. W., Cerullo, M. J., Raval, V., and Wong-On-Wing, B. 2000. Accounting Information System: Essential Concepts and Applications. New York: John Wiley \& Sons. Inc.

Winidyaningrum, Celviana dan Rachmawati. 2010. Pengaruh Sumber Daya Manusia dan Pemanfaatan Teknologi Informasi terhadap Keterandalan dan Ketepatwaktuan Pelaporan Keuangan Pemerintah Daerah dengan Variabel Intervening Pengendalian Intern Akuntansi (Studi Empiris di Pemda Subosukawonosraten). SNA XIII. 13-14 Oktober. Purwokerto.

Yaswat, Latifatul. 2015. Pengaruh Kompetensi Sumber Daya Manusia (SDM), Sistem Pengendalian Internal Pemerintah (SPIP) dan Penerapan Sistem Akuntansi Keuangan Daerah (SAKD) terhadap efektivitas pengelolaan keuangan daerah. Jurnal

Zainani, Elva. 2013. Pengaruh Faktor Internal dan Eksternal terhadap Keterandalan dan Ketepatwaktuan Pelaporan Keuangan Pemerintah Daerah (Studi Empiris pada Pemerintah Daerah Kabupaten Pesaweran). Jurnal. 